\title{
Cow Milk Contamination with Heavy Metals (Mercury and Lead) and the Possibility of Heavy Metals Disintegration by the Human Intestinal Bacteria
} Nastaran Soltani*

Department of Biology, Arsanjan Branch, Islamic Azad University, Iran

\begin{abstract}
Metal pollution in the environment and human diet represents a perennial problem and is detrimental to human health. Developed countries are seeking ways to find a solution for this problem. However, in developing countries such as Iran largely due to the lack of appropriate infrastructures, all people are exposed to the risk of heavy metals and nobody pays due attention to this problem. Bioremediation projects, in which bacteria are used, are currently an active field to solve the problem. The present study aimed to identify bacteria that might be used for disintegration of heavy metals in foods (cow's milk) in the intestines of humans. First, the amount of mercury and lead in cow's milk was determined by atomic absorption spectrophotometry and then 25 bacterial strains from the human intestine were purified and identified. After that, MIC test was conducted on the basis of resistance against heavy metals for 25 samples. To confirm the disintegration of heavy metals, bacterial biomass was isolated, and the atomic absorptions were assessed. Finally, bacterial DNAs were extracted and sequenced. The collected milk samples were contaminated with mercury and lead and 2 out of 25 collected samples were able to disintegrate heavy metals. The DNAs for the two bacteria were isolated, sequenced, and compared with other sequences in the GeneBank. The results revealed that the two isolated bacteria were new strains of $E$. coli. Finally, the resulting species were labeled and registered with the name of the authors in the NCBI website. Our findings indicated that two strains of E. coli were able to disintegrate heavy metals (mercury and lead) from foodstuffs (cow milk) in the intestinal tract of humans.
\end{abstract}

Keywords: Heavy metals (mercury and lead); Human intestinal bacteria; Cow milk; Disintegration of mercury and lead

\section{Introduction}

In the periodic table, elements with high atomic weight and metal properties at room temperature are referred to as heavy metals. They have a gravity of more than 5 gr per cubic centimeter. Mercury, lead and cadmium are not vital elements and have no beneficial effect on survival of living organisms. Thus, their accumulation in living organisms, especially in mammals, might cause serious diseases $[1,2]$. Heavy metals could enter the human food chain through various ways including wastewaters and sewage from factories, garbage, and dust. Food contamination by heavy metals might naturally contaminate foodstuffs for instance through contaminated soils [3,4]. Among neurological disorders caused by heavy metals, especially mercury, are IQ loss, decreased memory, autism, and eye and tongue-related disorders. There are generally two kinds of poisoning by lead: Chronic poisoning which is associated with antisocial behaviors, disordered hemoglobin synthesis, deafness, blindness, kidney dysfunction, mental disabilities, loss of sexual desire, and fatigue. The second type of lead poisoning is acute poisoning that might lead to nervous behavioral problems, convulsion, absent-mindedness, and nausea [5-7]. A large population of gram-negative bacteria, due to their special structure, has a high potential for entering and removing metals from the human body. Human body has the ability for detoxification which usually occurs in the intestine. In this process, the intestinal microbiota, lactobacillus, and probiotic bacteria are more likely to have a significant role in causing heavy metals to enter into and exit the body and in his way, protect their hosts $[5,7,8]$ as there is a complex balance between heavy metal pollutants and local microorganisms in environmental ecosystems $[1,9]$.

Methyl mercury is highly stable and soluble in fat and is more likely to attach to $\mathrm{SH}$ protein groups and thereby it might be stored in the muscular tissues and transferred in the form of the protein diet into the human body $[9,10]$. Another way for transferring methyl mercury into the food chain and into the body is via using fungicides and poisons containing mercury. Methyl mercury enters into other parts of the body through blood circulation and might hurt brain and kidneys [5,6]. Lead could also be accumulated in blood and bones. Furthermore, its halflife in the blood is about 30 days but it is able to remain in bones for years $[11,12]$. Heavy metals are accumulated through three ways: (1) connecting to the cell surface, (2) ionic exchange, and (3) intracellular accumulation $[7,13]$.

\section{Materials and Methods}

The samples of cow's milk were collected from a cattle farm and were sent to Parsian Beh Payesh Company in Bandar Abbas to assess their atomic absorption and to find out if they were contaminated with heavy metals or not. Besides, intestinal Entrobacters collected from faeces of children in Kosar Hospital in Shiraz were cultured and the contained bacteria were purified and identified. Kosar Hospital is one of the largest hospitals in shiraz (area of this study conduction) that generously supported the first author of this study by providing required data. In the next stage, MIC (Minimal Inhibitory Concentration) test [14] was performed for 25 collected samples and their resistance pattern was determined based on MIC in the culture medium containing chloride mercury and acetate lead. MIC has been defined as the lowest intensity a chemical (lead and mercury in our study) that does not allow a bacterium to grow [14]. In this method, a constant dilution assay should

*Corresponding authors: Nastaran Soltani, Department of Biology, Arsanjan Branch, Islamic Azad University, Tehran, Iran, Tel: 989177172151 E-mail: soltani.nastaran88@gmail.com

Received December 01, 2017; Accepted December 19, 2017; Published December 22, 2017

Citation: Soltani N (2017) Cow Milk Contamination with Heavy Metals (Mercury and Lead) and the Possibility of Heavy Metals Disintegration by the Human Intestinal Bacteria. J Med Microb Diagn 6: 267. doi:10.4172/2161-0703.1000267

Copyright: (c) 2017 Soltani N. This is an open-access article distributed under the terms of the Creative Commons Attribution License, which permits unrestricted use, distribution, and reproduction in any medium, provided the original author and source are credited. 
Citation: Soltani N (2017) Cow Milk Contamination with Heavy Metals (Mercury and Lead) and the Possibility of Heavy Metals Disintegration by the Human Intestinal Bacteria. J Med Microb Diagn 6: 267. doi:10.4172/2161-0703.1000267

Page 2 of 4

be conducted within number of tubes (10 tubes) for each agent (lead or mercury) [15]. 3 out of 25 strains were determined to be able to tolerate the heavy metals added to the medium. The bacterial growth and light absorption in the medium were then assessed through a wavelength of $580 \mathrm{~nm}$ to find out the growth hour in which bacteria enter the logarithmic phase. Then for each bacterium, 5 Erlenmeyer $(250 \mathrm{~mL})$ were added to $95 \mathrm{ml}$ of liquid medium and then were autoclaved. Next, for each $55 \mathrm{~mL}$ of bacteria under study that were contrasted with 5.0 McFarland were added. Additionally, given the calculated time for the algorithmic phase in the previous stage, flasks with concentrations of 1 , $0.5,0.25$, and 0.125 micro grams heavy metals and the fifth flask were used as treatments [15]. The flasks were transferred to the incubator 37 ${ }^{\circ} \mathrm{C}$ for 7 days and were exposed to 12 hours growth light absorption with the wavelength of $600 \mathrm{~nm}$. The bacteria with the highest absorption rate were then selected.

In the next stage, the three isolated strains were separately added into LB Broth containing $4 \mathrm{mg}^{1}$ of chloride mercury and acetate lead and were placed in the green house for 24 hours at $37^{\circ} \mathrm{C}$. The concentration of chloride mercury and acetate lead in which bacteria were able to grow was $4 \mathrm{mg}$. After the full growth of bacteria in the medium, it was centrifuged, and the lead was isolated from the surface liquid and rinsed with the distilled water. It was then placed in an oven for a whole night at $105^{\circ} \mathrm{C}$ so that the sediment became totally dehydrated. Afterwards, the water according to the guideline suggested by Clinical and Laboratory Standards Institute (CLSI) distilled for 2 times was added to it and the volume reached to $5 \mathrm{ml}$ and the supernatant was sterilized by a $0.45 \mu$ filter. Finally, the two solutions were placed in closed containers and were sent to the laboratory to read the atomic absorption solution. The results showed that bacterial factor played a major role in the disintegration of heavy metals from the environment as atomic absorption reduced in the solution but increased in the bacterial biomass.

Next, DNAs were extracted from bacteria using the DNA Extraction Kit from Genet Bio Corporation. The extracted DNAs were exposed to PCR tests using especial polymers related to 16 SrRNA. A part of gene (about $1000 \mathrm{bp}$ ) was remained. Fermentas Ladder (smo313) was used as the DNA ruler. PCR product underwent electrophoresis on agarose gel and Gel DNA Extraction kit (Roch Agarose) were also used to purify and prepare PCR. The resulting DNAs were sent to Bioneer in the South Korea for sequencing.

\section{Results}

The results from the sample of cow milk show that all 10 milk samples contained mercury. Further, the results of atomic absorption indicated that lead was higher than the standard level in 7 samples and was lower than the standard level in 2 samples and it was nonexistent in only 1 sample (Table 1 ).

The Table 2 represents the characteristics of each bacterium. Based on the bacterial comprehensive table, bacterial types and strains can be identified.

The results of MIC test showed that three strains of E. coli can tolerate mercury and lead more than other bacteria and thus they were excluded and studied.

The following tables shows the result of MIC test for three-strain $E$. coli isolated in Chloride mercury and lead acetate. In the tube 1 there was $10 \mathrm{ml}$ Nutrient Broth and $1 \mathrm{ml}$ of the agent (Chloride Mercury in

${ }^{1}$ According to the guidelines suggested by Clinical and Laboratory Standards Institute (CLSI)

\begin{tabular}{|c|c|c|}
\hline Milk sample number & Mercury dose $\mathbf{( m g / k g )}$ & Lead dose $\mathbf{( m g} / \mathbf{k g})$ \\
\hline Sample 1 & 0.00607 & 0.00147 \\
\hline Sample 2 & 0.0078 & 0.0073 \\
\hline Sample 3 & 0.0084 & 0.00000 \\
\hline Sample 4 & 0.0079 & 0.0045 \\
\hline Sample 5 & 0.0083 & 0.00000 \\
\hline Sample 6 & 0.0087 & 0.00000 \\
\hline Sample 7 & 0.0092 & 0.0072 \\
\hline Sample 8 & 0.0090 & 0.0047 \\
\hline Sample 9 & 0.0080 & 0.0056 \\
\hline Sample 10 & 0.0085 & 0.012 \\
\hline
\end{tabular}

These data are analysed and presented by Parsian Beh Payesh Company in Bandar Abbas, according to Iranian national standard 9266 and AOAC 971.21 following the internal standard operating procedure (SOP) number 056 and 059 .

Table 1: Atomic absorption of the milk samples

\begin{tabular}{|c|c|c|}
\hline No. & Bacteria & Number \\
\hline 1 & Anaerogenic E. coli & 2 \\
\hline 2 & Citrobacter & 1 \\
\hline 3 & E. coli & 12 \\
\hline 4 & Enterobacter & 4 \\
\hline 5 & Klebsiella & 1 \\
\hline 6 & Proteus mirabilis & 1 \\
\hline 7 & Pseudomonas & 1 \\
\hline 8 & Salmonela & 2 \\
\hline 9 & Shiegella & \\
\hline
\end{tabular}

Table 2: Identification of the bacteria collected.

\begin{tabular}{|c|c|c|c|c|c|c|c|c|c|c|}
\hline No. & $\begin{array}{c}\text { Tube } \\
1\end{array}$ & $\begin{array}{c}\text { Tube } \\
2\end{array}$ & $\begin{array}{c}\text { Tube } \\
3\end{array}$ & \begin{tabular}{|c|} 
Tube \\
4
\end{tabular} & $\begin{array}{c}\text { Tube } \\
5\end{array}$ & $\begin{array}{c}\text { Tube } \\
6\end{array}$ & $\begin{array}{c}\text { Tube } \\
7\end{array}$ & \begin{tabular}{|c|} 
Tube \\
8
\end{tabular} & $\begin{array}{c}\text { Tube } \\
9\end{array}$ & $\begin{array}{c}\text { Tube } \\
10\end{array}$ \\
\hline 1 & -4 & $+^{5}$ & + & + & + & + & + & + & + & + \\
\hline 2 & - & - & + & + & + & + & + & + & + & + \\
\hline 3 & - & + & + & + & + & + & + & + & + & + \\
\hline
\end{tabular}

Table 3: Results of MIC test for three-strain E. coli isolated in contact with chloride mercury.

\begin{tabular}{|c|c|c|c|c|c|c|c|c|c|c|}
\hline No. & Tube & Tube & Tube & Tube & Tube & Tube & Tube & Tube & Tube & Tube \\
& $\mathbf{2}$ & $\mathbf{3}$ & $\mathbf{4}$ & $\mathbf{5}$ & $\mathbf{6}$ & $\mathbf{7}$ & $\mathbf{8}$ & $\mathbf{9}$ & $\mathbf{1 0}$ \\
\hline 1 & - & + & + & + & + & + & + & + & + & + \\
\hline 2 & - & + & + & + & + & + & + & + & + & + \\
\hline 3 & - & + & + & + & + & + & + & + & + & + \\
\hline
\end{tabular}

Table 4: Results of MIC test for three-strain E. coli isolated in contact with lead acetate.

Table 3 and Lead Acetate in Table 4). The tube 2 included $10 \mathrm{ml}$ nutrient Broth and $1 \mathrm{ml}$ of the Tube 1's content. This process continued for all 10 tubes.

\section{Results of kinetic growth of mercury resistant bacteria}

The growth curve was plotted for 3 samples with the highest resistance. In the MIC test, all 3 samples entered the logarithmic phase after 30 minutes. To provide a kinetic analysis of growth, different concentrations of heavy metals were added into the medium after 30 minutes. After 7 days and after the analysis of the light absorption of the bacterial growth, it was observed that bacteria No. 2 and 3 in the concentration of 0.25 microgram and bacterium No. 1 in the concentration of 0.125 microgram showed the highest growth rates.

\section{Mercury atomic absorption in the supernatant}

Given that $4 \mathrm{mg}$ of mercury was added to the medium, there was 
no absorption in the solution containing bacterium No. 1 and the heavy metal did not reduce. In contrast, solutions containing bacteria No. 2 and 3 the absorption occurred, and the metal reduced (Table 5).

\section{The results of mercury atomic absorption in bacterial sediment (bacterial biomass)}

The atomic absorption happened in samples 2 and 3 and the bacteria were able to absorb heavy metals, but sample 1 was not able to do it (Table 6).

\section{The results of mercury atomic absorption in bacterial sediment (bacterial biomass)}

The atomic absorption happened in samples 2 and 3 and the bacteria were able to absorb heavy metals, but sample 1 was not able to do it (Table 7).

\section{The results of lead atomic absorption in the supernatant}

Since 4 milligrams lead was added into the medium, atomic absorption happened in three samples (1,2, and 3) and the heavy metals reduced (Table 8 ).

\section{Sequencing samples No. 2 and 3}

After extracting DNAs for bacteria No. 2 and 3, they were sent to Bioneer Company in South Korea and their gene sequences were determined. The resulting sequences were compared with other sequences in the international genetic bank in the US NCBI website using Blast Software. The results showed that the bacterial genes in both samples were $98 \%$ similar to $E$. coli. Then, these strains were labeled as E. coli (Msh 53) and E. coli (NS67) and were recorded by Tiba Company in Shiraz.

\section{Discussion}

Substances used to eradicate plants and vermin in places such as farms and gardens are transferred to rivers by rainwater and it might result in health and ecological hazards. Some of these substances are absorbed by plants and remain active in the plant growth cycle.

\begin{tabular}{|c|c|}
\hline Sample No. & Milligrams of mercury per litre of milk \\
\hline 1 & 3.95 \\
\hline 2 & 1.23 \\
\hline 3 & 0.81 \\
\hline
\end{tabular}

Table 5: Mercury atomic absorption in the supernatant.

\begin{tabular}{|c|c|}
\hline Sample No. & Milligrams of mercury per litre of milk \\
\hline 1 & 0 \\
\hline 2 & 2.03 \\
\hline 3 & 2.56 \\
\hline
\end{tabular}

Table 6: Mercury atomic absorption in bacterial sediment (bacterial biomass).

\begin{tabular}{|c|c|}
\hline Sample No. & Milligrams of lead per litre of milk \\
\hline 1 & 2.89 \\
\hline 2 & 2.89 \\
\hline 3 & 1.98 \\
\hline
\end{tabular}

Table 7: Lead atomic absorption in bacterial sediment (bacterial biomass)

\begin{tabular}{|c|c|}
\hline Sample No. & Milligrams of lead per litre of milk \\
\hline 1 & 0.34 \\
\hline 2 & 0.26 \\
\hline 3 & 0.56 \\
\hline
\end{tabular}

Table 8: Lead atomic absorption in the supernatant.
Furthermore, since animals eat the plants contaminated with insolvable poisons, their tissues and organs are deposited. Poisonous compounds are often heavy metals such as mercury, lead, and cadmium. These metals are transferred gradually until they reach higher levels that include human who eat such animals and act as the final hosts of these metals. They cause serious physical problems and even in some cases they lead to death. Bacteria, cyanobacteria, fungi, and yeasts are able to remove metal ions from the nearby environment due to their physicochemical mechanisms. For instance, living biomasses and their byproducts could store metal ions inside themselves. To remove heavy metals from farming wastewaters, the use of microbial technology especially different azotobacter species have captured the researchers' attention as a cost-effective approach. Scientists are looking for mechanisms to remove such metals from human food chain. In this study, intestinal bacteria were used to remove heavy metals in the cow milk. From all enterobacteriaceae samples collected, two samples were identified to be able to absorb the heavy metals such as mercury and lead and to excrete them through their feces. Therefore, such metals could not enter the human stomach and intestine through foodstuff to finally penetrate to the blood flow and also into bone tissues and the nervous system [6,16-18]. Chinikaar et al. studied four types of milk (raw milk, pasteurized milk, dry milk, and mother milk) to find out how they are contaminated with metals such as nickel, lead, copper, and cadmium using atomic absorption technique [19]. The results showed that $2.84 \%$ and $4.61 \%$ of the samples were contaminated by lead and cadmium. The average levels of lead, nickel, cadmium, and copper were equal to $1.2,42,14$, and $34 \mathrm{ppm}$, respectively. Tajkarimi et al. also conducted a study on 97 samples of unprocessed milk collected form milk tankers in 15 milk factories from different parts of Iran and assessed their contamination with lead using atomic absorption spectroscopy. The average levels of lead in samples were estimated at $7.9 \mathrm{ng} / \mathrm{mL}$. Less than $10 \%$ of the samples contained over $22 \mathrm{ng}$ lead per $\mathrm{mL}$ milk and in $60 \%$ of the samples, the average lead equaled 1.1 to 5.7 $\mathrm{ng} / \mathrm{mL}$. The milk samples collected from Isfahan, Tehran, and Eastern Azerbaijan contained the highest pollution levels [20]. The results of a study conducted by Nouri to measure levels of lead and cadmium in the cow milk in Isfahan using the atomic absorption spectroscopy with flame indicated that $83.33 \%$ of the samples were contaminated with cadmium that exceeded the standard level but the average level of lead was less than the standard values [21]

Additionally, Bonyadian carried out a study on the contamination of raw and pasteurized milk with lead and cadmium in Shahrekord using the spectroscopy technique [22]. In this study, 100 raw milk samples and 50 pasteurized milk samples were examined, and it was found that the confirmation levels of the samples with lead and cadmium were less than the standard level [22]. In addition, the mercury levels for all 10 samples were higher than the standard levels and a sample contained no lead. In contrast, the lead levels were higher than standard values in 2 samples. Also, a study conducted in the early 1980s showed how Bacillus subtilis is able to interact with a wide range of toxic metals such as copper, iron, magnesium, gold, lead, and mercury. This ability was due to the negative charge of bacteria and the positive charge of most of these metals. This implied that metals can penetrate in the bacterial cell walls [23]. Von Canstein et al., (1999) used LB medium and the temperature of $105^{\circ} \mathrm{C}$ to remove mercury resistant bacteria. Their method was similar to the method used in the present study. However, Spangler and colleagues [24] used Tryptic Soy Agar (TSA) and Bladi et al. [25] used tryptone iron agar as culture mediums. It seems that mediums containing heavy metals can be taken into consideration to remove mercury resistant bacteria [26]. Petrova and Mindlin observed resistance to heavy metals in a wide range of 
Citation: Soltani N (2017) Cow Milk Contamination with Heavy Metals (Mercury and Lead) and the Possibility of Heavy Metals Disintegration by the Human Intestinal Bacteria. J Med Microb Diagn 6: 267. doi:10.4172/2161-0703.1000267

Page 4 of 4

bacteria [27]. In the past studies, bacteria such as E. coli, Kelebsiella, Alcaligenes, Bacillus, Pseudomonas, Pseudomonas, and Acinetobacersp were reported as mercury resistant bacteria. The present study used Enterobacteriaceae and it was found that from the collected samples only E. coli was able to absorb mercury and lead. The concentration of chloride mercury and acetate lead in which the isolated were able to grow was $4 \mathrm{mg}$, while Horn et al. reported the resistance to chloride mercury in different strains of Pseudomonas putida was the highest in $35 \mathrm{mg}$ as the initial enrichment was performed in the presence of 10 $\mathrm{mg} / \mathrm{L}$ [28]. The initial enrichment resulted in the bacterial adaptation to the stress resulting from heavy metals and as a result the isolated bacteria were able to tolerate higher metal concentrations. One of the reasons accounting for the bacterial resistance in this study was the method used to isolated lead and mercury resistant bacteria. In most of the previously conducted studies, the isolation of such bacteria was done through direct culture in the solid medium containing chloride mercury and acetate lead and lower resistance values were reported. In this study, bacteria were grown in a liquid medium and then they were added to a medium containing heavy metal. This reduces the stress of bacteria when facing heavy metals [28]. Yulen et al. observed that a number of different bacteria and fungi such as Pseudomonas and Staphylococcus are able to reduce mercury levels. Moreover, they used ram-positive bacteria in their study while this study employed gram-negative bacteria, but it seems that the gram negative or positive bacteria have no absolute effect on the metal uptake [29].

\section{Conclusion}

The findings of this study indicated that intestinal bacteria might be used as a factor for biological disintegration of heavy metals in food exposed to heavy metals and enter the human body through the food cycle.

\section{Acknowledgements}

The author expresses her sincere thanks to Islamic Azad University of Arsanjan for its executive support in conducting this research project.

\section{References}

1. Adachi K, Tainosho $Y$ (2004) Characterization of heavy metal particles embedded in tire dust. Environ Int 30: 1009-1017.

2. Davis TA, Volesky B, Mucci A (2003) A review of the biochemistry of heavy metal biosorption by brown algae. Water Res 37: 4311-4330.

3. Schryvers AB, Stojiljkovic I (1999) Iron acquisition systems in the pathogenic Neisseria. Mol Microbiol 32: 1117-1123.

4. Vos G, Lammers H, Van Delft W (1988) Arsenic, cadmium, lead and mercury in meat, livers and kidneys of sheep slaughtered in the Netherlands. Z Lebensm Unters Forsch 187: 1-7.

5. Bellinger D, Leviton A, Waternaux C, Needleman H, Rabinowitz M (1987) Longitudinal analyses of prenatal and postnatal lead exposure and early cognitive development. N Engl J Med 316: 1037-1043.

6. Garcia-Salazar C, Gildow FE, Fleischer SJ, Cox-Foster (2000) Alimentary canal of adult Acalymma vittata (Coleoptera: Chrysomelidae): Morphology and potential role in survival of Erwinia tracheiphila (Enterobacteriaceae). Can Entomol 132: 1-13.

7. Monachese M, Burton JP, Reid G (2012) Bioremediation and tolerance of humans to heavy metals through microbial processes: A potential role for probiotics? Appl Environ Microbiol 78: 6397-6404.
8. François F, Lombard C, Guigner JM, Soreau P, Brian-Jaisson F, et al., (2012) Isolation and characterization of environmental bacteria capable of extracellular biosorption of mercury. Appl Environ Microbiol 78: 1097-1106.

9. Steinlin C, Huang J (2008) The role of microorganisms on mercury speciation in the environment. ETH Zurich, Switzerland.

10. Ullrich SM, Tanton TW, Abdrashitova SA (2001) Mercury in the aquatic environment: A review of factors affecting methylation. Crit Rev Environ Sci Technol 31: 241-293.

11. Dorea JG (2004) Mercury and lead during breast-feeding. Br J Nutr 92: 21-40.

12. Heard M, Chamberlain A (1984) Uptake of $\mathrm{Pb}$ by human skeleton and comparative metabolism of $\mathrm{Pb}$ and alkaline earth elements. Health Phys 47 : 857-865.

13. Lau MC (2011) Removal of lead ions from aqueous solution onto biomass of Bacillus subtilis. UTAR.

14. Tripathi K (2013) Essentials of Medical Pharmacology. JP Medical Ltd, UK.

15. Turnidge JD (2015) Susceptibility test methods: General considerations. In: Manual of Clinical Microbiology. (11th edn). American Society of Microbiology. p. $1246-1252$.

16. Fleming L, Watkins S, Kaderman R, Levin B, Ayyar DR, et al. (1995) Mercury exposure in humans through food consumption from the Everglades Florida. Mercury as a Global Pollutant. Springer 41-48.

17. Gavrilescu M (2004) Removal of heavy metals from the environment by biosorption. Eng Life Sci 4: 219-232.

18. Risher J, DeWoskin R (2005) Toxicological profile for mercury. Agency for toxic substances and disease Registry, Atlanta, Georgia.

19. Chinikaar SAA, Kodaei P, Asmar M, Saghiri R (1997) $4^{\text {th }}$ Congress of Biochemistry, Babol University of Medical Sciences. Babol, Iran. pp. 19-22.

20. Tajkarimi M, Faghih MA, Poursoltani H, Mahdavi H (2008) Lead residue levels in raw milk from different regions of Iran. Food Control 19: 495-498.

21. Noori SM (2004) Survey on the lead and cadmium level in consumers milk in Esfahan using atomic absorption spectrophotometery. Thesis No 318 (Faculty of Veterinary Medicine, ShahreKord Islamic Azad University, Iran.

22. Bonyadian M, Moshtaghi H, Soltani Z (2006) Determination of lead and cadmium in raw and pastoralized milk in Shahrekord ereas. Iran J Vet Med 74-81.

23. Fein JB, Martin AM, Wightman PG (2001) Metal adsorption onto bacteria surfaces: Development of a predictive approach. Geochimica et Cosmochimica Acta 65: 4267-4273.

24. Spangler WJ, Spigarelli JL, Rose JM, Flippin RS, Miller HH (1973) Degradation of methylmercury by bacteria isolated from environmental samples. Appl Microbiol 25: 488-493.

25. Baldi F, Boudou A, Ribeyre F (1992) Response of a freshwater bacteria community to mercury contamination $\left(\mathrm{HgCl}_{2}\right.$ and $\left.\mathrm{CH}_{3} \mathrm{HgCl}\right)$ in a controlled system. Arch Environ Contam Toxicol 22: 439-444.

26. Von Canstein H, Li Y, Timmis KN, Deckwer WD, Wagner-Döbler I (1999) Removal of mercury from chloralkali electrolysis wastewater by a mercuryResistant Pseudomonas putida strain. Appl Environ Microbiol 65: 5279-5284.

27. Petrova M, Mindlin SZ, Gorlenko ZhM, Kaliaeva ES, Soina VS, et al. (2002) Mercury-resistant bacteria from permafrost sediments and prospects for their use in comparative studies of mercury resistance determinants. Russ $\mathrm{J}$ Genet 38: $1330-1334$.

28. Horn JM, Brunke M, Deckwer WD, Timmis KN (1994) Pseudomonas putida strains which constitutively overexpress mercury resistance for biodetoxification of organomercurial pollutants. Appl Environ Microbiol 60: 357-362.

29. Yulan L, Lihua LQW (2007) A high sensitive and specific colorimetric mercury (II) biosensor [J]. Nuclear Techniques 5: 016. 